\title{
Masyarakat Adat versus Korporasi: Konflik Sosial Rencana Pembangunan Pabrik Semen di Kabupaten Pati Jawa Tengah Periode 2013-2016
}

\author{
Suharko
}

\begin{abstract}
Social conflict between indigenous community of Sedulur Sikep and PT SMS has arisen as a consequence of utilization of karst for cement plant in District of Pati, Central Java since 2010. Using secondary data collected from off line and on line media, and applying Wehr's model of conflict mapping, the article aims to map the conflict. For the corporation, karst can be mined and has a high economic value. For Sedulur Sikep, karst must be conserved because it covers water reservoir that is vital for its agricultural livelihood. From 2010 to 2014, while Sedulur Sikep continuesly rejected the establishment of the plant, PT SMS had completed environmental impact analysis. After Head of Pati district launched an environmental licence for PT SMS in the end of 2014, the two parties of conflict had been head to head in two levels of the administrative courts (PTUN Semarang and PTTUN Surabaya). The verdicts of court are not able to end the conflict yet. Opportunity to solve the conflict will depend on the results of strategic environmental analysis (KLHS) that was decided by the President as a reference for parties who plan to mine karst in mountain of Kendeng Utara, Central Java.
\end{abstract}

\section{Keywords:}

social conflict; karst; indigenous community; corporation; conflict mapping; conflict resolution.

\begin{abstract}
Abstrak
Konflik sosial antara PT SMS dan masyarakat adat Sedulur Sikep terjadi sebagai akibat dari upaya pemanfaatan batu kapur untuk pabrik semen di Kabupaten Pati, Jawa Tengah sejak tahun 2010. Dengan menggunakan data sekunder dari berbagai sumber media cetak dan online, serta merujuk pada model pemetaan konflik Wehr, artikel ini berupaya untuk memetakan konflik tersebut. Bagi korporasi, batu kapur bisa ditambang dan memiliki nilai ekonomi tinggi; sedangkan bagi masyarakat adat, batu kapur harus dilestarikan karena di bawahnya terdapat cadangan air yang penting bagi usaha pertanian. Dari tahun 2010 hingga 2014, Sedulur Sikep dan jejaring pendukungnya selalu menolak pendirian pabrik semen. Pada saat yang sama, PT SMS melakukan sosialisasi dan menyusun dokumen analisis dampak lingkungan. Setelah terbit Izin Lingkungan oleh Bupati Pati pada akhir 2014, kedua pihak berhadapan di dua tingkat pengadilan tata usaha negara, yakni PTUN Semarang dan PTTUN Surabaya. Putusan pengadilan belum mampu mengakhiri konflik ini. Peluang penyelesaian konflik bergantung pada hasil Kajian Lingkungan Hidup Strategis yang diputuskan oleh Presiden sebagai acuan bagi semua pihak yang akan menambang batu kapur di pegunungan Kendeng Utara, Jawa Tengah.
\end{abstract}

\section{Kata kunci:}

konflik sosial; batu kapur; masyarakat adat; korporasi; pemetaan konflik; resolusi konflik.

\footnotetext{
- Dosen Departemen Sosiologi FISIPOL UGM.

Email: suharko@ugm.ac.id
} 


\section{Pendahuluan}

Konflik sosial yang mengiringi suatu rencana usaha industri yang memanfaatkan sumberdaya alam (SDA) dan secara potensial bisa menimbulkan dampak penting terhadap lingkungan hidup terjadi di sejumlah daerah di Indonesia. Konflik sosial tersebut pada umumnya melibatkan masyarakat lokal (termasuk masyarakat adat) dan korporasi yang didukung pemerintah daerah. Konflik antara masyarakat lokal yang tergabung dalam Paguyuban Petani Lahan Pasir (PPLP) dan PT Jogja Magasa Iron (JMI) terjadi sejak korporasi tersebut mengumumkan rencana penambangan pasir besi di Kulon Progo pada pertengahan tahun 2000-an. Sementara korporasi yang didukung pemerintah pusat dan daerah tersebut berhasil membangun pabrik pengolahan pasir besi, PPLP yang didukung Organisasi Masyarakat Sipil (OMS) terus menolaknya (Astuti, 2012). Masyarakat lokal berhadapan dengan korporasi (PT Panggon Sarkarya Sukses Mandiri) terjadi di Kota Batu, Jawa Timur seiring rencana pembangunan hotel yang mengancam kelestarian mata air Umbul Gemulo. Meskipun masyarakat setempat sempat memenangkan gugatan di Pengadilan Negeri Malang, pada akhirnya mereka dikalahkan oleh pengajuan kasasi ke MA oleh perusahaan tersebut (Riski, 2016). Sementara itu masyarakat adat di Bali yang didukung OMS, akademisi, dan budayawan, berhadapan dengan PT Tirta Wahana Bali Internasional (TWBI) yang telah memiliki rujukan legal Peraturan Presiden (Perpres) No. 51/2014 untuk melakukan proyek reklamasi Teluk Benoa, Bali (Apriando, 2014). Sementara tahapan proses menuju konstruksi proyek tersebut berjalan, aksi-aksi penolakan oleh masyarakat adat di Bali terus terjadi, dan belum ada indikasi penyelesaian konflik. Kasuskasus konflik serupa yang mengiringi rencana pengembangan atau ekspansi industri terjadi di berbagai daerah.

Salah satu kasus yang menarik perhatian publik secara luas adalah konflik sosial yang mengiringi rencana pembangunan pabrik semen dengan memanfaatkan batu kapur atau batu gamping (karst) di Kabupaten Pati, Jawa Tengah. Konflik sosial ini memperhadapkan antara masyarakat lokal atau adat dan korporasi semen yang telah berlangsung sejak tahun 2008. Pada awalnya, masyarakat adat berhadapan dengan PT Semen Gresik (kemudian berubah menjadi PT Semen Indonesia) pada tahun 20082009. Setelah kemenangan gugatan masyarakat adat di PTUN Semarang dan PT Semen Gresik membatalkan investasinya pada tahun 2009, korporasi semen yang lain, PT Sahabat Mulia Sakti (SMS) berupaya melakukan investasi semen di Pati sejak 2010. Konflik yang memperhadapkan masyarakat adat dan korporasi semen pun kembali terjadi hingga kini (Oktober 2016).

Konflik ini mendapatkan perhatian publik secara luas, sebagaimana tampak dari liputan media online dan cetak, dan tanggapan publik melalui media sosial. Seiring dengan itu, sejumlah analisis konflik pun ditawarkan terutama oleh para aktivis OMS. Novianto (2014) melihat bahwa rencana pembangunan pabrik semen adalah bagian dari ekspansi kapitalisme yang didukung negara (pemerintah) dan kemudian dilawan oleh masyarakat setempat yang terancam. Aktivis WALHI, Ning Fitri (2014) menyatakan bahwa rencana pendirian pabrik semen oleh PT SMS telah menimbulkan konflik antara kelompok yang pro dan kontra di dalam masyarakat, dan dengan mempertimbangkan potensi dampak lingkungan yang akan terjadi, maka rencana tersebut harus dihentikan. Bahkan sebuah rumah produksi, Watchdog (2015), menggambarkan konflik ini melalui film dokumenter di laman Youtube "SAMIN vs SEMEN". Tulisan-tulisan tersebut tidak menggunakan model analisis konflik yang ketat untuk memahami konflik. Analisis tersebut juga cenderung bias kepada kepentingan salah satu pihak utama yang berkonflik. Pada titik ini penting untuk mengembangkan analisis konflik dengan model yang ketat agar mampu 
memahami konflik secara lebih komprehensif dan yang secara indikatif mampu memberikan arah menuju penyelesaian konflik.

Penulis telah memetakan konflik sosial tersebut dari tahun 2010 sampai akhir 2012. Sampai akhir tahun 2012, konflik masih berlangsung secara intens; dan memasuki tahun 2013, seiring dengan terpilihnya Ganjar Pranowo sebagai Gubernur, muncul harapan kuat terhadap penyelesaian konflik ini (Suharko, 2013). Namun harapan tersebut berlalu dengan berjalannya waktu, dan konflik tetap berlanjut. Artikel ini bertujuan memetakan konflik sosial tersebut dari tahun 2013 hingga Agustus 2016, sebagai kelanjutan dari pemetaan konflik dari tahun 2010 sampai tahun 2012.

\section{Kerangka Analisis dan Metode Penelitian}

Konflik memiliki makna ketidaksesuaian (incompatibility) yang terjadi diantara dua pihak atau lebih. Merujuk the Dictionary of Conflict Resolution (1999, dalam Morasso, 2008) konflik adalah "the broader state of incompatibility that may or may not give rise to a dispute". Dengan demikian, konflik merupakan kondisi ketidaksesuaian diantara tujuan-tujuan dari dua pihak atau lebih yang bisa memunculkan terjadinya sengketa (dispute).

Artikel ini memaparkan konflik antara masyarakat adat dan korporasi. Masyarakat adat adalah "komunitas-komunitas yang hidup berdasarkan asal-usul leluhur secara turun-temurun di atas suatu wilayah adat, yang memiliki kedaulatan atas tanah dan kekayaan alam, kehidupan sosial budaya yang diatur oleh hukum adat dan lembaga adat yang mengelola keberlangsungan kehidupan masyarakatnya" (Aman, tanpa tahun). Masyarakat adat dalam tulisan ini adalah komunitas Sedulur Sikep (SS) atau komunitas Samin, sedangkan korporasi atau perusahaan berbentuk Perseroan Terbatas (PT), sesuai dengan Pasal 1 UU PT No. 40/2007 adalah badan hukum yang merupakan persekutuan modal, didirikan berdasarkan perjanjian, melakukan kegiatan usaha dengan modal dasar yang seluruhnya terbagi dalam saham. Dalam kaitan ini yang dimaksud korporasi adalah PT Sahabat Mulia Sakti (SMS).

Konflik sosial berjalan secara dinamis. Sandole (1998) membedakan tiga bentuk proses konflik. Konflik laten terjadi ketika setidaknya dua pihak memiliki tujuan-tujuan yang tidak saling bersesuaian (mutually incompatible goals). Proses konflik manifes (manifest conflict process) terjadi ketika setidaknya dua pihak atau representasinya mengejar tujuan-tujuan mereka yang saling tidak bersesuaian dengan meruntuhkan (undermining), baik secara langsung maupun tidak langsung, kemampuan masing-masing dalam mencapai tujuan. Sedangkan proses konflik manifes agresif (agressive manifest conflict process) adalah situasi ketika setidaknya dua pihak, atau representasiya, berupaya mengejar tujuantujuan yang tidak saling bersesuaian dengan merusak secara fisik barang-barang dan simbolsimbol dengan nilai tinggi dari masing-masing pihak; dan atau melukai, merusak, secara fisik dan psikologis, atau menghilangkan satu sama lain. Ketika situasi konflik berkembang ke konflik manifes agresif, kedua pihak memperlihatkan tindakan yang mengarah kepada kekerasan baik secara psikologis maupun secara fisik.

Salah satu cara terbaik untuk memahami kecenderungan dan pola dari suatu konflik adalah pemetaan konflik (conflict mapping) (Askandar, 2000). Pemetaan konflik merupakan salah satu kerangka kerja analisis dari berbagai bentuk kerangka kerja analisis konflik (Fisher et.al, 2000). Menurut Wehr (1979: 18), “mapping is a first step in intervening to manage a particular conflict". Hasil dari pemetaan konflik menjadi basis untuk menyusun strategi pengelolaan dan penyelesaian konflik.

Wehr (1979) menawarkan pemetaan konflik yang mencakup sejumlah aspek penting. Pertama, pemaparan tentang sejarah 
konflik yang mencakup mengenai asal-usul dan peristiwa-peristiwa penting dalam evolusi konflik. Kedua, konteks konflik yang melatari terjadinya konflik, yang antara lain mencakup konteks geografis dan fisik, ekonomi dan politik. Ketiga, pihak yang berkonflik baik yang terlibat secara langsung dalam konflik maupun secara tidak langsung atau memiliki kontribusi di dalam dinamika konflik. Pihak yang berkonflik terbagi antara pihak utama dan pendukung (primary and secondary parties). Keempat, isu konflik yakni titik ketidaksesuaian yang harus diselesaikan. Isu konflik dapat diidentifikasi dan dikelompokkan sesuai dengan faktor utama yang menimbulkan konflik, yakni berbasis fakta (facts-based), nilai (values-based), kepentingan (interests-based) dan di luar ketiganya, aspek non-realistik (nonrealistic). Aspek berikutnya, kelima adalah dinamika konflik. Aspek ini berkaitan dengan proses perjalanan dan evolusi konflik yang mencakup peristiwa yang mengawali, akselerasi menuju puncak konflik, dan proses peredaan konflik. Pemaparan aspek-aspek di atas, mendasari aspek keenam, yakni jalan alternatif untuk solusi masalah dan potensi pengaturan konflik. Dalam kaitan ini ditemukan bentuk-bentuk upaya yang pernah dilakukan untuk menyelesaikan masalah, dan potensi untuk pengaturan konflik.

Sandole (1998) mengembangkan pendekatan atau model tiga pilar untuk memetakan konflik pada level laten, manifes hingga manifes agresif. Pilar 1 merupakan analisis terhadap konflik secara khusus yang terdiri dari pihak, isu, tujuan, sarana, orientasi, dan lingkungan konflik. Unsur-unsur pilar 1 ini tampak pararel dengan model Wehr. Pilar 2 berkaitan dengan sebab dan kondisi konflik. Analisis pada pilar ini mencakup sebab-sebab pada individual, masyarakat, internasional, dan global/ekologikal. Analisis juga berupaya menemukan peyebab munculnya tindak kekerasan dalam konflik. Sedangkan pilar 3 berkaitan dengan intervensi konflik yang mencakup pencegahan konflik, manajemen konflik, penyelesaian konflik (conflict settlement), resolusi konflik, transformasi konflik (provention).

Bright (tanpa tahun) mengembangkan conflict mapping chart yang merupakan kombinasi antara model Wehr dan pendekatan Sandole. Chart ini terdiri dari enam komponen, dan masing-masing komponen memiliki sejumlah elemen. Keenam komponen tersebut adalah pihak, sejarah, konteks, orientasi pihak, dinamika, dan intervensi konflik. Elemenelemen yang menyusun komponen-komponen tersebut kurang lebih sama dengan yang ada pada model Wehr dan pendekatan Sandole.

Dari tinjauan singkat terhadap modelmodel pemetaan konflik tersebut, model Wehr merupakan platform dari model-model pemetaan konflik yang terus berkembang hingga saat ini. Tidak berlebihan jika berbagai lembaga studi konflik atau yang terlibat dalam penanganan konflik, pada umumnya mengembangkan pedoman pemetaan konflik yang berbasis pada model Wehr (misalnya, the Institute for Conflict Analysis and Resolution George Mason University; The Conflict Information Consortium, University of Colorado).

Lebih dari itu, dibandingkan dengan model tiga pilar Sandole, model Wehr memberikan porsi yang memadai untuk melihat aspek dinamika konflik. Sandole tidak secara spesifik menyebutkan aspek ini dalam unsur-unsur yang membentuk pendekatan tiga pilarnya. Dalam konteks proses konflik yang dinamis, penggambaran tentang dinamika konflik ini menjadi sangat penting dalam pemetaan konflik.

Mendasarkan pada argumen tersebut, artikel ini menggunakan model Wehr sebagai kerangka kerja analisis untuk memahami konflik antara masyarakat adat dan korporasi di Kabupaten Pati. Sebagaimana telah dikemukakan pada bagian awal, artikel ini merupakan kelanjutan dari pemetaan konflik rencana pendirian pabrik semen di Pati tahun 2010-2012. Pada aspek sejarah, pihak, 
dan isu konflik, tulisan ini akan merujuk ke artikel sebelumnya (Suharko, 2013) dengan tambahan data terbaru yang diperoleh, karena sebenarnya tidak terjadi perubahan penting dalam kedua aspek tersebut. Selanjutnya, artikel ini memberikan penekanan pada tiga aspek; yakni konteks, dinamika, dan resolusi konflik. Konteks (politik) konflik mengalami perubahan karena terjadi pergantian gubernur dan presiden. Proses pendirian pabrik semen yang terus berjalan dan perubahan konteks politik tersebut berimplikasi pada dinamika konflik dan resolusi konflik.

Terdapat dua pendekatan terkait dengan resolusi konflik, yakni litigasi melalui lembaga peradilan dan penyelesaian sengketa alternatif (alternative dispute resolution-ADR) (Carneiro et.al, 2014), seperti mediasi, negosiasi, intervensi dari pihak yang lebih tinggi, peran pihak ketiga yang netral, dan bentuk-bentuk penyelesaian konflik lainnya. Keduanya memiliki keterbatasan dan kelebihan masingmasing. Pendekatan litigasi menghasilkan suatu kepastian, dalam bentuk keputusan pengadilan. Namun, proses litigasi berlangsung dalam situasi yang formal di pengadilan, sehingga masing-masing pihak terbawa dalam atmosfer yang kompetitif untuk memaksimalkan apa yang bisa dimenangkan. Proses litigasi juga cenderung tidak efektif dari aspek waktu dan biaya. Proses persidangan bisa berjalan lama karena adanya berbagai prosedur dan mekanisme hukum yang kompleks. Hal ini kadang ditambah lagi dengan "permainan" antar aparat penegak hukum yang menjadikan keputusan pengadilan tidak memiliki legitimasi yang kuat bagi semua pihak.

Sementara itu, ADR berlangsung dalam situasi yang lebih informal. Para pihak yang berkonflik dan juga mediator bisa mengembangkan suasana kooperatif untuk memperoleh kesepakatan bersama dan mengikat kedua pihak. Namun demikian, para pihak menghadapi masalah ketika tidak ada kondisi yang memaksa mereka untuk bertemu sebagaimana terjadi pada proses pengadilan. Masing-masing pihak seringkali tidak memiliki posisi tawar yang seimbang, sehingga menyulitkan dalam proses negosiasi dan memperoleh kesepakatan yang memuaskan kedua pihak.

Data yang digunakan untuk memetakan konflik ini adalah data sekunder, yakni informasi dan peristiwa yang ditulis dan dilaporkan oleh berbagai pihak dan narasumber melalui media massa, baik yang bersifat on-line maupun offline (cetak). Pemberitaan dan laporan terkait dengan pernyataan, pendapat, dan ungkapan dari para pihak yang berkonflik, serta aktivitas yang melibatkan para pihak yang berkonflik secara relatif intens dimuat di media massa cetak dan online, baik media lokal maupun nasional. Seiring dengan perkembangan teknologi informasi, pernyataan, ungkapan, aktivitas dan peristiwa konflik ini juga direkam dan didokumentasikan melalui film, dan selanjutnya diunggah di Youtube dan situssitus tertentu yang dimiliki suatu organisasi dan perorangan. Informasi dan peristiwa yang tersaji dalam media massa tersebut relatif gencar, mengiringi proses perjalanan rencana pembangunan pabrik semen di kawasan pegunungan Kendeng Utara, Jawa Tengah.

Semua informasi dan peristiwa yang termuat dalam media massa tersebut menyediakan basis data yang relatif memadai untuk mengembangkan analisis pemetaan konflik sosial berbasis sumberdaya alam ini. Melalui analisis isi, data yang dikumpulkan melalui akses dan unduhan dari media-media tersebut, dicermati detilnya, selanjutnya informasi yang relevan dipilih dan dipilah, untuk dikembangkan ke dalam kategorisasi. Hasil dari semua itu dipergunakan untuk membangun deskripsi dan mengembangkan pemetaan konflik sosial.

Penggunaan data sekunder dari media massa memiliki keterbatasan untuk mengungkap banyaknya para pihak yang terlibat dalam konflik. Media massa cenderung 
melaporkan para pihak utama dalam konflik, dan kurang memberikan perhatian kepada pihak-pihak pendukung yang berada di balik para pihak utama, termasuk latar belakang pelaku dan alasan memberikan dukungan. Oleh karena itu, tanpa mengabaikan adanya banyak pihak pendukung, artikel ini berfokus pada pemetaan konflik antara pihak-pihak utama yang terlibat dalam konflik.

\section{Sejarah Singkat Konflik}

Pada tahun 2007, PT Semen Gresik berencana melakukan ekspansi usaha dengan membangun pabrik semen di Kecamatan Sukolilo, Kabupaten Pati. Ekspansi ini mendapatkan perlawanan keras dari masyarakat adat Sedulur Sikep (SS) atau Samin, yang didukung oleh OMS. Masyarakat adat SS tidak hanya menegaskan penentangannya melalui aksi-aksi kolektif, seperti demonstrasi, pernyataan sikap, dan berbagai bentuk ritual sosial lainnya, tetapi juga melalui gugatan ke Pengadilan Tata Usaha Negara (PTUN) Semarang. Pada akhirnya, PTUN memenangkan gugatan masyarakat adat SS, dan pihak PT Semen Gresik membatalkan rencana investasi pabrik semen di Kabupaten Pati. Korporasi tersebut kemudian memindahkan rencana pendirian pabrik semen di Kabupaten Rembang. Korporasi semen ini telah berhasil melampaui tahap pra-konstruksi, dan memasuki tahap konstruksi, serta direncanakan pada bulan Oktober 2016 dilakukan percobaan operasi pabrik (Kompas 13 April 2016). Namun demikian, seiring dengan proses konstruksi pabrik semen tersebut, konflik sosial kembali terjadi antara masyarakat adat SS yang didukung berbagai OMS berhadapan dengan korporasi yang didukung pemerintah daerah. Konflik yang semula terjadi di Kabupaten Pati, kemudian berpindah lokasi ke Kabupaten Rembang.

Kegagalan PT Semen Gresik membangun pabrik semen di Kabupaten Pati ternyata tidak mengendorkan ekspansi korporasi semen yang lain. Pada tahun 2010, PT SMS mulai merealisasikan rencana untuk mendirikan pabrik semen di Kecamatan Tambakromo dan Kayen, Kabupaten Pati. Untuk bisa mendirikan pabrik semen, PT SMS harus mendapatkan izin lingkungan (sesuai PP No. 27/2012) dari Bupati Pati. Dengan menunjuk sebuah perusahaan konsultan penyusun AMDAL dari Semarang, PT SMS mulai melakukan kajian dan penyusunan dokumen AMDAL pada tahun 2010. Dalam kenyataannya, proses penyusunan AMDAL yang secara normatif bisa selesai dalam hitungan bulan, berlangsung berlarut-larut dalam hitungan tahun. Hal ini terjadi karena aksi-aksi penolakan masyarakat adat SS yang didukung sejumlah OMS terhadap proses penyusunan AMDAL. Hingga akhir tahun 2012, PT SMS belum berhasil menyelesaikan dokumen tersebut (Suharko, 2013). Sebagaimana akan ditunjukkan pada bagian selanjutnya, PT SMS menyelesaikan penyusunan dokumen AMDAL pada tahun 2014, dan kemudian diikuti oleh terbitnya Surat Izin Lingkungan dari Bupati Pati, sekaligus membuka babak baru konflik sosial antara masyarakat adat SS dan PT SMS.

\section{Konteks (Politik) Konflik}

Konflik ini memiliki konteks yang beragam mencakup aspek fisik, geografis, ekonomi dan sosial yang telah dipaparkan dalam tulisan sebelumnya (Suharko, 2013). Bagian ini memaparkan konteks politik yang mengalami perubahan karena dua peristiwa politik penting. Yang pertama adalah terpilihnya Ganjar Pranowo sebagai Gubernur Jawa Tengah pada Mei 2013. Ganjar yang mantan anggota DPR dari PDIP dikenal sebagai politisi muda yang progresif dan dikenal dekat dengan berbagai OMS dan kalangan akar rumput, seperti petani, nelayan dan pelaku usaha kecil lainnya. Tidak berlebihan jika masyarakat adat SS dan OMS berharap bahwa Gubernur bisa membantu merealisasikan tujuan mereka. Tidak berselang lama setelah pemilihan 
gubernur Jawa Tengah, tokoh perempuan masyarakat adat SS, Gunarti, memberikan hadiah berupa hasil pertanian dan air dari pegunungan Kendeng Utara kepada Gubernur, dengan menyatakan: "Ini adalah harapan besar kami sebagai rakyat kecil, kami berharap Pak Ganjar bisa ngayomi, bisa memperjuangkan kami" (regional.kompas.com, 23 Agustus 2013). Perlu dicatat bahwa pada pemerintahan sebelumnya (Bibit Waluyo), Gubernur tampak lebih condong pada kepentingan korporasi.

Perjalanan konflik menjadi lebih dramatis seiring terpilihnya Joko Widodo sebagai Presiden pada tahun 2014. Gaya kepemimpinan dan pendekatan sosial yang dipergunakan terhadap rakyat bawah oleh Jokowi sejak menjadi Walikota Solo, Gubernur DKI Jakarta, dan kemudian Presiden, memberikan harapan dan peluang baru terutama bagi masyarakat adat SS untuk menyelesaikan konflik sosial ini. Menurut Gunarti, setelah terpilih meski belum dilantik menjadi Presiden, Jokowi pernah menjanjikan pertemuan dan diskusi dengan warga. Gunarti mengatakan: “... dia berjanji kalau sudah dilantik akan mengajak warga berdiskusi bersama. Kalau memang pembangunan industri itu tidak layak, ya pabrik semen harus pergi" (regional.kompas. com, 6 April 2015).

Sebagaimana akan tersaji pada bagian selanjutnya, kedua pejabat politik tersebut memainkan peran penting dalam upaya resolusi konflik ini. Sebagai pejabat politik yang memiliki kewenangan besar, keduanya tidak hanya memberikan ruang politik yang memadai, namun juga menyediakan peran penting dalam resolusi konflik ini.

\section{Pihak-pihak yang Berkonflik}

Dalam perjalanankonflik, masyarakatadat SS tampil sebagai pihak utama dan kekuatan inti yang melawan PT SMS (dan bahkan korporasi semen lain yang memanfaatkan batu kapur di kawasan pegunungan Kendeng Utara). Masyarakat adat SS mendapatkan dukungan dari Pusat Studi, Advokasi, dan Dokumentasi Hak-hak Masyarakat Adat (Pusaka); Yayasan Desantara; Aliansi Masyarakat Adat Nusantara (AMAN); dan OMS lainnya baik di tingkat lokal maupun nasional.

Salah satu OMS tersebut adalah Pemuda Nahdatul Ulama (NU) yang tergabung dalam Front Nahdliyin untuk Kedaulatan Sumber Daya Alam (FN-KSDA) simpul Pati. Bersama dengan sejumlah organisasi yang menentang pabrik semen, FN-KSDA membentuk sebuah “Laskar Kendeng". Mereka mendeklarasikan wadah gerakan tersebut pada tanggal 1 Januari 2014. Deklarasi diadakan di depan Posko Pemuda Peduli Pegunungan Kendeng dengan cara membubuhkan tanda tangan di atas kain putih sebagai bentuk penolakan terhadap rencana indutri semen di wilayah mereka (omahkendeng.org, 4 Januari 2014).

Dua tokoh penting dari masyarakat adat SS adalah Gunretno, dan adik perempuannya Gunarti. Dalam keseharian dan ketika tampil ke publik, Gunretno selalu mengenakan pakaian khas masyarakat adat SS yaitu baju warna hitam dengan mengenakan celana sampai di bawah lutut dan mengenakan udeng di kepalanya. Gunarti sangat aktif terlibat dalam aksi-aksi penolakan, terutama untuk memobilisasi kaum perempuan.

Jaringan Masyarakat Peduli Pegunungan Kendeng (JMPPK) didirikan pada tahun 2008 ketika masyarakat adat SS berjuang menolak pendirian pabrik semen di Sukolilo oleh PT Semen Gresik. Jaringan menjadi wadah bagi berbagai pihak, terutama OMS yang simpati dan mendukung aksi penolakan terhadap pabrik semen. JMPPK terus aktif dalam perjuangan menolak pabrik semen di sekitar pegunungan Kendeng Utara yang meliputi wilayah Kabupaten Grobogan, Pati, Kudus, Rembang, dan Blora. Melalui JMPPK, Gunretno berhasil membangun jejaring dengan kalangan akademisi, politisi, agamawan, dan aktivis OMS. JMPPK aktif memanfaatkan media online berupa laman (omahkendeng.org), Facebook 
dan Twitter untuk membangun jejaring dan menarik dukungan. Laman omahkendeng selalu update dan memuat berbagai informasi dan data yang terkait dengan upaya penolakan terhadap pabrik semen di pegunungan Kendeng Utara.

Gunretno lebih sering mengedepankan posisi sebagai "koordinator" atau "perwakilan" JMPPK daripada sebagai tokoh masyarakat Samin atau Sedulur Sikep dalam menjalankan aksi-aksi penolakan terhadap korporasi semen. Hal ini mengandaikan bahwa JMPPK berupaya tampil sebagai wadah bagi semua pihak, baik perorangan maupun organisasi, yang menentang korporasi semen. Meskipun demikian, sulit dipungkiri bahwa kelompok inti dari JMPPK adalah masyarakat adat SS dengan Gunretno sebagai tokoh sentralnya.

Sementara itu, PT SMS mendapatkan dukungan dari pemerintah Kabupaten Pati. PT SMS adalah anak perusahaan PT Indocement Tunggal Prakasa, yang sudah kurang lebih 40 tahun mengoperasikan pabrik semen di Jawa Barat. Komposisi pemegang sahamnya, PT Mekar Perkasa 13 persen, Birchwood Omnia Ltd (Hidelberg Cement / HC group) 51 persen, Publik 36 persen. Korporasi ini mengoperasionalkan 12 pabrik dengan lokasi 9 pabrik di Citeureup Bogor, dua pabrik di Palimanan Cirebon, dan satu pabrik di Terjun Kalimantan Selatan. Perusahaan ini sedang membangun satu pabrik lagi di Citeureup Bogor (Fitri, 2014).

Korporasi semen ini akan menginvestasikan 4-5 triliun rupiah untuk mendirikan pabrik semen (Kompas, 22 Mei 2011). Dengan investasi yang besar tersebut, pemerintah daerah Kabupaten Pati memandang bahwa kehadiran pabrik semen akan mendorong perkembangan ekonomi daerah terutama melalui penyerapan tenaga kerja dan kontribusi korporasi terhadap Pendapatan Asli Daerah (PAD). Pemda Pati memberikan dukungan kebijakan yang diperlukan untuk kelancaran realisasi investasi pabrik semen, terutama melalui perubahan peraturan tentang rencana tata ruang wilayah (RTRW) yang menempatkan pegunungan Kendeng Utara dalam kawasan industri dan sekaligus kawasan lindung konservasi (Kompas, 2 Maret 2013).

\section{Isu Konflik}

Pokok persoalan yang membawa dua pihak utama yakni masyarakat adat SS dan PT SMS dalam relasi konfliktual adalah pemanfaatan batu kapur dan air di kawasan pegunungan Kendeng Utara, Jawa Tengah.

Masyarakat adat SS dan jejaring pendukungnya berpandangan dan bahkan meyakini bahwa sumberdaya alam yang ada di pegunungan Kendeng Utara mutlak untuk dilestarikan dan tidak untuk ditambang. Setiap upaya untuk mengubah kondisi ekosistem pegunungan akan mengganggu keseimbangan alam. Pemanfaatan batu kapur untuk bahan baku semen, dipandang bisa mengancam kelestarian cadangan air yang tersimpan di bawah batuan kapur. Padahal sumberdaya air adalah sumber kehidupan penting bagi masyarakat adat SS yang meyakini bahwa satu-satunya pola nafkah adalah bertani, dan pantang untuk berdagang (Efendi, 2013). Dalam ungkapan Hartati (istri Gunretno), masyarakat adat SS boleh berdagang asalkan barang yang dijual lebih murah harganya daripada saat barang tersebut dibeli. Ia mengatakan: "Itu merupakan cara halus untuk mengingatkan kami agar tetap memegang jalan hidup bertani" (Kompas, 14 April 2016).

Bagi masyarakat adat SS, bertani bukan hanya cara hidup tetapi juga hidup itu sendiri. Karena itu, sawah adalah tempat aktivitas utama mereka. Sawah tidak akan menghasilkan apa-apa tanpa ketersediaan air. Pada titik inilah, masyarakat adat SS memandang bahwa setiap bentuk eksploitasi terhadap sumberdaya alam di pegunungan Kendeng Utara adalah ancaman bagi kehidupan mereka. Sedangkan bagi PT SMS, ketersediaan batu kapur yang menghampar di pegunungan dan cadangan 
air di bawahnya adalah sumberdaya alam yang harus dimanfaatkan untuk kepentingan ekonomi. Melalui proses kimiawi, batu kapur dan batu lempung bisa diubah menjadi semen yang bernilai ekonomi tinggi. Pendirian dan operasi pabrik semen tidak akan merusak atau mematikan sektor pertanian. PTSMS mengklaim bahwa pabrik semen yang dioperasikan oleh induk perusahaannya tidak menimbulkan dampak pada hilangnya sumberdaya air. PT SMS menantang pihak yang menolak pabrik semen dengan pernyataan: "Silakan mengecek pabrik kami yang sudah eksis di daerah lain. Apakah sawah di sekitar kering tidak?" (Kompas, 13 April 2016).

Sedangkan bagi pemerintah daerah, minat investor dan korporasi untuk membuka industri di wilayahnya adalah sesuatu yang dinanti dan bahkan diundang. Semakin banyak pelaku usaha terutama korporasi bersedia melakukan investasi dan membuka usaha ekonomi dan industri, maka semakin besar peluang untuk meningkatkan PAD. PT SMS mengklaim akan menyumbang PAD melaui pajak galian $\mathrm{C}$, pemanfaatan air permukaan, pajak penerangan jalan umum, pajak bumi dan bangunan (PBB), serta berbagai pajak maupun retribusi sesuai dengan peraturan daerah (www.antarajateng.com, 21 Maret 2016). Tidak berlebihan jika salah satu tolok ukur keberhasilan kinerja kepala daerah adalah besaran PAD yang mampu diakumulasi. Alasan inilah yang seringkali membawa posisi kepala daerah untuk lebih berpihak kepada kepentingan korporasi daripada berpihak kepada kepentingan masyarakat, yang seringkali merasa dirugikan dengan kehadiran korporasi.

Lebih dari itu, baik bagi korporasi maupun bagi pemda, pembukaan dan juga ekspansi industri semen akan mendatangkan manfaat ekonomi yang signifikan, karena dianggap mampu menciptakan kesempatan kerja bagi masyarakat setempat. PT SMS mengklaim bahwa sekitar 3.000 pekerja akan diserap pada tahap konstruksi pabrik semen (www.antarajateng.com, 21 Maret 2016). Sedangkan pada saat pengoperasian pabrik semen akan memberikan kesempatan kerja bagi 300 orang untuk kualifikasi tenaga berkemampuan khusus, 500 orang tenaga kerja biasa, dan 500 orang tenaga kerja di luar pabrik (Kompas, 22 Mei 2011). Penyerapan tenaga kerja setempat seperti ini diasumsikan akan membuka jalan bagi upaya meningkatkan kesejahteraan masyarakat.

\section{Dinamika Konflik}

Dinamika konflik sosial antara masyarakat adat SS dan PT SMS dalam rentang waktu tahun 2013 hingga akhir Agustus 2016 dapat dibagi ke dalam tiga episode yang didasarkan pada perubahan arena pertentangan masingmasing pihak. Episode pertama berkaitan dengan penyelesaian dokumen AMDAL oleh PT SMS sebagai syarat untuk mendapatkan izin lingkungan. Tarik ulur kepentingan antara dua pihak utama yang berkonflik pada episode kedua dan ketiga berpusat pada gugatan masing-masing pihak ke lembaga pengadilan. Namun sebelum ketiga episode tersebut disajikan, akan disampaikan secara ringkas dinamika konflik pada periode tahun 2010-2012.

Sejak PT SMS mengumumkan rencana untuk mendirikan pabrik semen pada tahun 2010, masyarakat adat SS dan jejaring pendukungnya secara kontinu menegaskan posisi dan kepentingan dasarnya, yakni menolak pabrik semen. Bentuk penolakan itu antara lain tampak dari tuntutan kepada Bupati untuk mencabutizin lokasi yang telah diberikan kepada PT SMS, dan aksi mengganggu proses penyusunan Amdal dengan menghambat akses tim penyusun ke lapangan untuk mengumpulkan data. Di pihak lain, meskipun diganggu dan dihambat oleh masyarakat adatSS dan jejaring pendukungnya, melalui konsultan penyusun AMDAL yang ditunjuknya, PT SMS terus berupaya menyelesaikan dokumen 
tersebut. Sementara PT SMS tetap mengantongi izin lokasi dari Bupati, sampai akhir tahun 2012, tim penyusun belum merampungkan dokumen AMDAL sebagai basis rujukan untuk menerbitkan izin lingkungan oleh Bupati (Suharko, 2013).

\section{Episode Pertama (2013-2014)}

Memasukitahun2013 hingga pertengahan tahun 2014, PT SMS yang didukung oleh Pemda Pati terus berupaya menyelesaikan AMDAL. Sidang komisi AMDAL untuk menentukan kelayakan lingkungan dari rencana pembangunan pabrik semen akhirnya dilakukan pada tanggal 3 September 2014 di Hotel Pati. Status kelayakan lingkungan inilah yang menjadi dasar rujukan bagi Bupati Pati untuk menerbitkan izin lingkungan bagi PT SMS. Sidang ini mendapatkan penjagaan keamanan yang ketat dari gabungan TNI/Polri dan Satpol PP Pati karena ratusan masyarakat adat SS dan JMPPK melakukan aksi teatrikal dan orasi untuk menyatakan penolakan proses AMDAL yang hanya akan melancarkan jalan bagi PT SMS untuk mendirikan pabrik semen (pasfmpati.com, 3 September 2014; jatengtribunnews.com, 21 Agustus 2014). Seorang aktivis JMPPK, Bambang Sutikno mengatakan: "Kami membaca dan menganalisis dokumen AMDAL dan menurut kami tidak beres. Seharusnya AMDAL dibatalkan, karena dalam dokumen AMDAL jelas bahwa 67 persen warga menolak pabrik semen, 20 persen setuju dan 13 persen tidak menentukan sikapnya" (Mongabay.co.id, 18 Januari 2016).

Meskipun ditentang oleh masyarakat adat SS dan JMPPK, komisi penilai AMDAL pada akhirnya menyepakati kesimpulan dokumen tersebut bahwa rencana pendirian pabrik semen memenuhi syarat kelayakan lingkungan. Hal itu tertuang dalam Surat Keputusan Kelayakan Lingkungan (SKKL) No 660.1/4766 tahun 2014 berikut rekomendasi bernomor 660.1/012/XII/Amdal/2014. Kedua surat tersebut menjadi rujukan bagi Bupati Pati untuk menerbitkan izin lingkungan bagi PT SMS (suaramerdeka.com, 8 Januari, 2015).

Aksi penolakan pabrik semen oleh masyarakat adat SS dan JMPPK juga digelar melalui ritual adat. Pada tanggal 3 Oktober 2014, dari pagi hingga malam, mereka menggelar rembuk warga tentang kedaulatan pangan dan ritual "lamporan" di Sukolilo, Kabupaten Pati. Menurut Amrih Widodo, peneliti masyarakat adat Samin dari Australian National University, yang hadir pada ritual ini, lamporan adalah ritual masyarakat agraris Jawa. Menurutnya:"Ritual ini biasanya dimaksudkan untuk mengusir lampor atau kekuatan jahat. Bagi petani, lampor bisa mewujud hama perusak tanaman dan berbagai penyakit yang dianggap ancaman. Kali ini, yang dianggap ancaman besar adalah pabrik semen" (mongabay.co.id, 6 Oktober 2014).

Masyarakat yang datang dalam ritual tersebut kebanyakan petani, yang berasal dari kawasan Pegunungan Kendeng Utara (Pati, Purwodadi, Blora, Rembang), dan bahkan ada warga yang datang dari kawasan karst Maros-angkep, Sulawesi Selatan. Laki-laki, perempuan, anak-anak hingga dewasa, antusias mengikuti ritual tersebut. Keragaman peserta ritual tampak dari penampilan. Beberapa perempuan berjilbab, sebagian berkebaya hitam berkain jarit. Sebagian lelaki berkopiah dan kain sarung, lainnya bersurjan hitam, bercelana komprang berikat udeng. Sejumlah tokoh yang selama ini mendukung masyarakat adat SS dan petani di sekitar pegunungan Kendeng Utara turut hadir dalam acara tersebut. Mereka adalah Hermanu Triwidodo dan Soeryo Adi Wibowo (IPB), Eko Teguh Paripurno (UPN Yogyakarta), Hendro Sangkoyo (School of Democratic Economy), Gus Zaim Uchrowi dan Gus Baehaqi (tokoh agama Rembang), Alissa Wahid (putri mantan Presiden Abdurrahman Wahid) dan Bondan Gunawan (mantan Menteri Sekretaris Negara) (nationalgeographic.co.id, 13 Oktober 2014).

Desember 2014, terbit Surat Keputusan (SK) Bupati Pati Nomor: 660.1/4767/2014 yang memuat izin lingkungan pabrik semen dan 
penambangan batu gamping dan batu lempung kepada PT SMS. SK ini merupakan ujung dari proses penyusunan dokumen AMDAL yang dimulai sejak 2011. Berbekal izin lingkungan, secara legal formal, PT SMS bisa memulai tahap konstruksi pabrik semen. Keluarnya izin lingkungan ini berarti kemenangan bagi PT SMS atas masyarakat adat SS dan JMPPK.

\section{Episode Kedua (Tahun 2015)}

Merespon terbitnya izin lingkungan tersebut, pada April 2015, masyarakat adat SS mengajukan gugatan ke PTUN Semarang. LBH Semarang bertindak sebagai kuasa hukum dari penggugat yang terdiri dari lima orang, yakni Jasmo, Wardjo, Paini, Samiun, dan Sardjudi melawan Bupati Pati, Haryanto dan PT SMS. Mereka menuntut pembatalan SK Bupati Pati No: 660.1/4767 tahun 2014 tentang Izin Lingkungan Pembangunan Pabrik Semen serta Penambangan Batugamping dan Batulempung oleh PT SMS di Kabupaten Pati, Jawa Tengah. Mereka mendaftarkan gugatan ke PTUN pada 4 Maret 2015. Namun, sidang tidak segera digelar karena majelis hakim meminta penggugat untuk melakukan perbaikan berkas gugatan, terutama terkait laporan kronologi munculnya SK Bupati tentang izin lingkungan dan penambangan bagi PT SMS.

Selain menggugat melalui PTUN Semarang, di sela-sela persidangan, sejumlah warga Pati yang menentang pendirian pabrik semen melakukan audiensi dengan Gubernur Ganjar Pranowo (regional.kompas, 4 Agustus, 2015). Mereka mengadukan Bupati Pati karena dinilai tidak mau mendengarkan aspirasi terkait rencana pendirian pabrik Semen di kawasan pegunungan Kendeng Utara. Mereka juga meminta Gubernur untuk mengunjungi desa-desa yang akan menjadi tapak pabrik semen agar tahu kondisi yang sesungguhnya (regional.kompas.com, 13 Agustus 2015).

Menjelang sidang PTUN untuk menyampaikan putusan, ratusan warga yang menolak pabrik semen dari Pati dan daerah lain di kawasan pegunungan Kendeng Utara yang memakai atribut JMPPK melakukan long march (berjalan kaki) sepanjang $122 \mathrm{~km}$, dari Sukolilo, Pati, melewati Kudus dan Demak, dan sampai PTUN Semarang. Mereka melakukan perjalanan mulai minggu malam tanggal 15 November setelah mengikuti ritual lamporan. Mereka menyebut aksi ini "Kendeng Menjemput Keadilan" (m.tempo. co, 8 November 2015).

Aksi ini menarik perhatian dari netizen di media sosial, melalui berbagai tagar, salah satunya adalah \#Menjemput Keadilan. Melalui media sosial, netizen turut mengawal perjuangan JMPPK. Melalui tagar di media sosial yang mereka kibarkan, publik bisa "menyentuh" wajah-wajah penuh lelah para petani yang menolak pendirian pabrik semen dengan cara search, retweet, like, hingga tweet. Dengan mencari di Twitter, Path hingga Facebook masyarakat pun seolah bisa turut langsung dalam perlawanan masyarakat adat SS dan JMPPK.

Pada tanggal 17 November 2015, Hakim PTUN Semarang membacakan putusan yang mengabulkan gugatan warga. SK Bupati Pati Nomor 660.1/4767/2014 tertanggal 8 Desember 2014 tentang izin lingkungan pembangunan pabrik semen dan penambangan batu gamping dan lempung oleh PT SMS dinyatakan batal demi hukum. Hakim mewajibkan tergugat (Bupati Pati) mencabut surat keputusan tersebut. Alasan yang dipertimbangkan hakim untuk memenangkan gugatan warga penolak pabrik semen adalah kesesuaian lokasi pabrik semen dengan dokumen rencana tata ruang dan wilayah (RTRW) dan asas umum penyelenggaraan pemerintahan yang baik. Selain itu, hakim menilai bahwa proses AMDAL tidak sepenuhnya melibatkan masyarakat sekitar yang terdampak.

Masyarakat adat SS dan JMPPK menyambut keputusan tersebut dengan suka cita. Tokoh perempuan masyarakat adat SS, Gunarti, menyatakan lega sambil menyatakan: "Sekarang kami menang lagi. Setelah ini kami 
berharap tidak akan ada lagi pabrik semen yang mau berdiri di wilayah Kendeng" (rappler.com, 18 November 2015). Ini adalah kemenangan mereka yang kedua terhadap korporasi semen yang mau membangun pabrik di Pati, sebelumnya mereka memenangkan gugatan yang sama terhadap PT Semen Gresik di PTUN Semarang pada tahun 2009.

\section{Episode Ketiga (Januari - Agustus 2016 )}

Kemenangan masyarakat adat SS dan jejaring pendukungnya hanya bersifat sementara. Terhadap keputusan PTUN Semarang, PT SMS dan Bupati Pati mengajukan tiga memori banding ke Pengadilan Tinggi Tata Usaha Negara (PTTUN) Surabaya pada awal 2016. Memori banding tersebut diajukan oleh Bupati Pati dan PT SMS melalui kuasa hukumnya Abdul Hakim Garuda Nusantara, Harman dan Partner, dan PT SMS melalui kuasa hukumya Yusril Ihza Mahendra dan Partner. PT SMS mengajukan 29 pokok-pokok keberatan terhadap alasan dan pertimbangan yang menjadi dasar pengambilan keputusan oleh hakim PTUN Semarang. PT SMS berharap majelis hakim tingkat banding dapat memeriksa dan memutus perkara tersebut secara obyektif dan profesional (www. antarajateng.com, 21 Maret 2016). Di pihak lain, kuasa hukum warga masyarakat adat SS dan jejaring pendukungnya, LBH Semarang, mengirimkan 3 kontra memori banding ke PTTUN Surabaya pada 4 Maret 2016. LBH berupaya memperkuat kembali argumen dan alasan serta bukti pendukung yang diajukan oleh warga masyarakat adatSS, dengan harapan PTTUN Surabaya mengukuhkan keputusan hakim PTUN Semarang. Disamping itu LBH mengirimkan surat ke PTTUN Surabaya agar hakim pemeriksa perkara ini adalah hakim yang bersertifikasi lingkungan (omahkendeng. org, 11 Maret 2016).

Selama menunggu hasil keputusan PTTUN Surabaya, masyarakat adat SS dan JMPPK menggelar 2 kali aksi di depan lembaga pengadilan tersebut. Melalui aksi tersebut, mereka berupaya menjaga asa agar keputusan Hakim PTTUN memihak kepada kepentingan mereka. Aksi tersebut juga dilandasi kekhawatiran bahwa keputusan Hakim PTTUN akan berakhir sama, yakni ketika kemenangan mereka di PTUN Semarang (tahun 2009) akhirnya dibatalkan oleh PTTUN Surabaya (tahun 2010) dalam kasus perlawanan mereka terhadap rencana pendirian pabrik semen di Sukolilo oleh PT Semen Gresik.

Aksi yang pertama digelar pada 24 Februari 2016. Melalui aksi bertajuk "Kendeng Njejegke Adil" (Kendeng Menegakkan Keadilan), lebih dari 200 warga masyarakat adat SS dan JMPPK mendatangi PTTUN Surabaya. Mereka berupaya mengetuk hati dan pikir dengan menyampaikan pesan melalui doa dan audensi kepada majelis Hakim yang akan memutus banding gugatan terhadap izin lingkungan pendirian pabrik dan penambangan PT SMS (walhijatim.or.id, Februari 2016).

Mereka kembali menggelar aksi unjuk rasa di depan PTTUN Surabaya pada 2 Juni 2016. Sebagian diantara mereka adalah para perempuan yang mengenakan pakaian tradisional Jawa dan membawa bendera merah putih. Sembari menyampaikan orasi dan puisi, untuk kedua kalinya mereka mengetuk hati hakim yang menangani Banding PT SMS dan Bupati Pati mampu menghasilkan keputusan yang memihak kepada kepentingan mereka (tribunnews.com, 2 Juni 2016).

Kekhawatiran masyarakat adat SS dan JMPPK mendapatkan konfirmasi dari putusan hakim PTTUN Surabaya tertanggal 1 Juli 2016 dan dibacakan pada 14 Juli 2016 yang memenangkan banding PT SMS dan Bupati Pati. Putusan ini membatalkan putusan PTUN Semarang bernomor register 015/G/2015/PTUN. SMG, tertanggal 17 November 2015, yang memenangkan gugatan masyarakat adat SS yang menolak Izin Lingkungan yang diberikan kepada PT SMS oleh Bupati Pati (patikab.go.id, 3 Agustus 
2016). Terhadap Putusan Hakim PTTUN ini, tokoh masyarakat adatSS, Gunretno menyatakan: "Kami akan ajukan kasasi ke Mahkamah Agung atas putusan PTTUN Surabaya" (wartapantura. com, 12 Agustus, 2016). Hal ini berarti bahwa konflik sosial ini masih akan terus berlanjut, dan secara legal-formal akan diselesaikan melalui lembaga pengadilan tertinggi, yakni MA.

\section{Penyelesaian Konflik melalui Lembaga Pengadilan (Litigasi)}

Penyelesaian konflik melalui lembaga pengadilan (litigasi) dipilih dan didorong oleh Gubernur untuk ditempuh oleh kedua pihak utama yang berkonflik. Gubernur mengklaim dirinya berdiri sebagai pihak yang netral, tidak berpihak pada PT SMS dan masyarakat adatSS. Bagi Gubernur lembaga pengadilan bisa berdiri netral dalam mengambil keputusan terhadap benturan kepentingan dua pihak yang sulit dipertemukan. Bahkan Ia meminta agar semua pihak yang berkepentingan, termasuk para ahli (pertambangan, geologi, dan ahli ilmu alam lainnya) yang berbeda pandangan tentang boleh tidaknya batur kapur di pegunungan Kendeng Utara ditambang untuk membawa bukti kajian ilmiah ke sidang pengadilan sebagai basis data bagi para hakim dalam mengambil keputusan (youtube.com, Ganjar dan Semen Rembang).

Terkait dengan penolakan terhadap izin lingkungan, Gubernur mendorong masyarakat adat SS dan jejaring pendukungnya untuk mengajukan gugatan ke pengadilan tata usaha negara. Ia mengatakan: "Yang Pati, Rembang selalu saya arahkan pada gugatan. Saya ikuti sebagai eksekutif, Gubernur. Kalau (rakyat) menang, tidak pernah ada pabrik semen," (Kompas, 26 April 2016). Ia meminta agar mereka mengawal proses hukum yang berjalan dengan menyampaikan bukti dan argumen penolakan ke lembaga pengadilan. Dalam hal ini, hanya lembaga pengadilan (dan bukan Gubernur) yang bisa membatalkan izin lingkungan yang telah diterbitkan (youtube. com, Gubernur Ganjar Melihat Tapak Semen Tambakromo).

Sambil mendorong penyelesaian melalui jalur pengadilan, untuk meredam aksi-aksi kolektif yang bisa mengarah kepada tindak kekerasan, Gubernur terlibat aktif dalam berbagai pertemuan dengan pihak-pihak yang menentang pabrik semen. Gubernur mendengarkan aspirasi dan kepentingan mereka, dan meminta mereka untuk tidak bertindak anarkis, seperti melalui blokade jalan Pati-Kudus pada 13 Juli 2015 (Solopos. com, 14 Juli 2015), dan bentuk aksi kekerasan lainnya. Gubernur meminta mereka untuk menyampaikan penolakan dengan cara yang santun. Gubernur juga memfasilitasi aksi-aksi demonstrasi warga penolak pabrik semen agar aksi berjalan tertib dan tidak menimbulkan gangguan ke publik.

Upaya mediasi juga dilakukan oleh Gubernur untuk mempertemukan warga Pati yang menolak pabrik semen dengan Bupatinya pada tanggal 12 Agustus 2015 malam di Pendopo Kabupaten Pati. Mereka berdiskusi terkait penerbitan izin lingkungan untuk PT SMS dalam suasana cair, santai, dan terbuka untuk umum. Meskipun proses dialog berjalan terkendali, pada akhirnya tidak ada titik temu antara Bupati Pati dan warga yang menolak pabrik semen. PT SMS tetap mengantongi izin lingkungan, dan hanya jalur pengadilan yang bisa membatalkan izin tersebut. Dengan adanya dinamika konflik yang berjalan, pada akhirnya Gubernur dan kedua pihak yang berkonflik tampak mengandalkan pada mekanisme dan lembaga pengadilan (PTUN dan PTTUN) untuk menyelesaikan konflik. Meskipun masyarakat adat SS dan jejaring pendukungnya menolak proses penyusunan AMDAL dan implikasi kebijakannya dalam bentuk Izin Lingkungan oleh Bupati Pati, mereka tidak bisa memaksa Bupati dan juga kepala pemerintahan yang lebih tinggi untuk membatalkannya. Secara prosedural legal, izin lingkungan yang diterbitkan oleh Bupati 
adalah sah, dan hanya lembaga pengadilan yang bisa membatalkannya.

Lembaga pengadilan memang mampu memberikan keputusan yang definitif dan tegas. Namun dalam praktiknya, proses hukum di lembaga pengadilan menimbulkan ketidakpastian. Dalam kasus konflik ini, keputusan yang sudah diambil di tingkat PTUN bisa dibatalkan di PTTUN, dan proses pun berlanjut ke MA, sampai ada suatu keputusan yang benar-benar mengikat dan final. Selama masih ada peluang dan mekanisme hukum untuk mengubah hasil keputusan, pihak yang kalah akan selalu menempuh langkah hukum. Lebih dari itu, proses tersebut memakan waktu yang lama, prosedur dan mekanisme hukum yang bertingkat-tingkat, dan pada akhirnya menimbulkan biaya sosial dan ekonomi yang besar. Bagi masyarakat adat SS dan jejaring pendukungnya tentu hal tersebut akan menyedot energi sosial dan ekonomi yang besar; sementara bagi korporasi hal tersebut berarti ketidakpastian atau penundaan realisasi investasi. Karena itu, konflik ini sebenarnya menimbulkan dampak negatif yang serius bagi kedua pihak.

Keputusan dari lembaga pengadilan acapkali juga problematik, terutama bagi masyarakat adatSS dan jejaring pendukungnya, karena dalam pandangan mereka, para hakim tidak berdiri netral dan juga tidak bebas dari intervensi kekuatan besar dalam mengambil suatu keputusan. Pandangan seperti itu terasa masuk akal karena munculnya kasus-kasus yang mengindikasikan adanya praktik mafia dan korupsi (penyuapan) yang melibatkan jaksa dan hakim. Pada titik ini, keputusan lembaga pengadilan menjadi tidak legitimate dan sangat mungkin untuk tidak dipatuhi oleh pihak yang merasa dikalahkan.

\section{Alternatif Resolusi Konflik: Peran Lembaga Kepresidenan}

Masyarakat adat SS dan jejaring pendukungnya, bisa jadi menyadari keterbatasan dari penyelesaian konflik melalui lembaga pengadilan tersebut. Mereka mencari alternatif penyelesaian konflik lain dengan berupaya menarik keterlibatan lembaga kepresidenan, sebagai institusi pemerintahan tertinggi. Langkah ini dilakukan sejak Jokowi terpilih sebagai Presiden pada tahun 2014. Janji politik Jokowi untuk melakukan dialog dengan masyarakat adat SS merupakan pintu masuk untuk menuntut lembaga kepresidenan dalam penyelesaian konflik ini.

Upaya yang dilakukan untukmewujudkan tuntutan tersebut antara lain dengan menggelar sejumlah aksi di depan Istana Negara Jakarta. Dengan dukungan dari sejumlah OMS di Jakarta seperti LBH Jakarta dan Kontras, mereka melakukan aksi teatrikal. Sembilan perempuan yang berasal dari Pati, Grobogan, dan Rembang yang menyebut diri sebagai 'Kartini Kendeng' melakukan aksi mengecor kaki mereka di seberang Istana Negara pada tanggal 12 April 2016 (internasional.kompas.com, 14 April 2016). Mereka mengakhiri aksi dengan cara menghancurkan semen yang membelenggu sepasang kaki mereka pada sore hari tanggal 13 April 2016 ketika utusan Presiden, Kepala Staf Kepresidenan Teten Masduki dan Menteri Sekretaris Negara Pratikno mendatangi mereka. Karena alasan kepadatan jadwal kegiatan Presiden, dan sembari menjamin komitmen Presiden untuk menemui mereka, kedua Utusan tersebut berjanji untuk mengagendakan pertemuan mereka dengan Presiden (nasional. tempo.co, 14 April 2016).

Setelah melakukan sejumlah demonstrasi dan aksi teatrikal di depan Istana Merdeka, akhirnya Presiden Joko Widodo bertemu dan berdiskusi dengan 17 orang perwakilan warga yang menolak pembangunan pabrik semen di pegunungan Kendeng Utara dan dipimpin oleh tokoh masyarakat adat SS, Gunretno, dan didampingi oleh Soeryo Adiwibowo (IPB) di Istana Negara, pada Selasa, 2 Agustus 2016. Presiden Jokowi memutuskan bahwa eksplorasi batu kapur di Pegunungan Kendeng Utara, Jawa Tengah tidak akan dilakukan sebelum ada 
Kajian Lingkungan Hidup Strategis (KLHS). Kajian tersebut akan memastikan bahwa aktivitas penambangan batu kapur tidak berdampak buruk bagi warga dan lingkungan, termasuk ketersediaan air bersih (Kompas, 3 Agustus 2016).

Keputusan yang diambil Presiden untuk melakukan KLHS sebelum dilakukan penambangan batu kapur untuk bahan baku industri semen memberikan pijakan awal untuk penyelesaian konflik sosial berbasis sumberdaya alam ini. Hasil KLHS akan menjadi rujukan bagi pemerintah pusat, pemda, investor, dan masyarakat setempat dalam menyikapi rencana penambangan batu kapur untuk pabrik semen. Terkait KLHS, Soeryo Adiwibowo mengatakan:

“...salah satu jalan melihat daya dukung dan daya tampung seluruh Pegunungan Kendeng sehingga bisa dilihat mana yang akan membahayakan tata air di wilayah sekitar, mana yang bisa ditoleransi". Kepala Staf Kepresidenen, Teten Masduki menyatakan: "Ini jalan keluar terbaik bagi kemelut persoalan pabrik semen ini" (Kompas, 3 Agustus 2016).

Kedua pihak yang terlibat dalam konflik memberikan respon yang berbeda terkait keputusan Presiden tersebut. Masyarakat adat SS dan jejaringnya yang bergabung dalam JMPPK menyambut antusias keputusan ini. Mereka mendukung langkah ini sembari menuntut agar KLHS dilakukan secepatnya dengan melibatkan mereka dalam proses kajian. Sementara itu, pihak PT SMS tidak memberikan pernyataan resmi terkait keputusan Presiden tersebut (murianews. com, 4 Agustus 2016). Apapun tanggapan masing-masing pihak yang berkonflik, mereka harus mematuhi keputusan Presiden tersebut. Pertanyaan yang muncul kemudian adalah apakah hasil KLHS nantinya benar-benar mampu menjadi rujukan ilmiah bagi semua pihak dalam menyelesaikan konflik ini?
Dengan memperhatikan respon dan komitmen dari para pihak yang berkonflik terhadap KLHS ini, jawaban terhadap pertanyaan tersebut akan bergantung kepada kualitas hasil kajian. Dua hal pokok akan menentukan kualitas hasil kajian, yakni siapa yang melakukan dan bagaimana kajian dilakukan.

Kepala Staf Kepresidenan akan mengkoordinasi pelaksanaan KLHS yang melibatkan sejumlah kementerian/lembaga dan pemerintah daerah. Kementerian Lingkungan Hidup dan Kehutanan (LHK) adalah ketua panitia pengarah KLHS (Kompas, 4 Agustus 2016). KLHS akan dilakukan selama satu tahun. Selama kajian berlangsung, tidak diperbolehkan melakukan eksploitasi batu kapur, dan diberlakukan moratorium izin lingkungan untuk pabrik semen di kawasan Pegunungan Kendeng Utara. Hingga akhir Agustus 2016, belum ada informasi resmi tentang struktur tim kajian yang akan melakukan KLHS.

KLHS adalah "rangkaian analisis yang sistematis, menyeluruh dan partisipatif untuk memastikan bahwa prinsip pembangunan berkelanjutan telah menjadi dasar dan terintegrasi dalam pembangunan suatu wilayah dan/atau kebijakan, rencana, dan/atau program" (UU No. 32/2009 tentang Pengelolaan dan Perlindungan Lingkungan Hidup, pasal 1 ayat 10). Mekanisme KLHS cukup sederhana, yakni mengkaji kebijakan, rencana dan program (KRP) dengan mengikuti skenario indikator daya dukung dan daya tampung, merumuskan alternatif penyempurnaan KRP tersebut, dan akhirnya memberikan rekomendasi perbaikan untuk pengambilan keputusan KRP yang mengintegrasikan pembangunan berkelanjutan. Menurut Menteri LHK, bila hasilnya relevan, KLHS bisa merekomendasikan AMDAL yang baru. KLHS secara umum memberi kesempatan tidak hanya kepada perusahaan untuk menyempurnakan dokumen AMDAL, tetapi juga melindungi lingkungan yang sangat penting bagi masyarakat sekitar (Kompas, 4 Agustus 2016). 
Oleh karena itu, sementara KLHS telah diterima oleh para pihak utama sebagai titik tolak dari penyelesaian konflik, perlu ada ketegasan dari pemerintah pusat (Presiden) bahwa apapun yang diputuskan sebagai implikasi dari hasil KLHS harus dipatuhi oleh para pihak yang berkonflik. Kesediaan dan komitmen untuk patuh terhadap keputusan pemerintah inilah yang akan menjadi kunci dari penyelesaian konflik ini di masa datang.

\section{Kesimpulan}

Konflik antara masyarakat adat SS dan korporasi semen di Pati sudah berlangsung sejak 2008 dan belum berakhir. Gejala penggunaan kekerasan psikologis dan fisik oleh masingmasing pihak mengindikasikan adanya pergeseran dari proses konflik manifes ke proses konflik manifes agresif. Himbauan agar kedua pihak tidak menggunakan cara-cara yang anarkis dalam mengejar tuntutannya, dan menempuh jalur pengadilan, menguatkan indikasi dari pergeseran bentuk proses konflik tersebut.

Kedua pihak utama memiliki tujuan yang saling tidak bersesuaian. Dari aspek isu, konflik ini berbasis nilai dan sekaligus kepentingan. Dari dimensi nilai, masyarakat adat meyakini bahwa batu kapur dan ekosistem yang melingkupinya harus dilestarikan; sementara bagi korporasi, batu kapur adalah sumberdaya alam yang bisa dimanfaatkan untuk peningkatan kesejahteraan masyarakat. Dilihat dari dimensi kepentingan, bagi masyarakat adat, kelestarian ekosistem pegunungan Kendeng Utara akan menyediakan sumberdaya air untuk menjamin pola kehidupan pertanian mereka; sementara bagi korporasi, pemanfaatan sumberdaya alam di kawasan pegunungan tersebut akan meningkatkan keuntungan usaha dan sekaligus berimplikasi pada pendapatan ekonomi daerah dan nasional.

Dinamika konflik ditandai oleh peristiwaperistiwa penting yang berimplikasi pada posisi yang konfrontatif. Periode awal konflik sampai akhir tahun 2014, kedua pihak menegaskan dan memperjuangkan tujuannya dalam proses penyusunan dokumen AMDAL dan penerbitan Izin Lingkungan oleh Bupati Pati. Setelah terbitnya Izin Lingkungan, kedua pihak berkonfrontasi langsung di ruang pengadilan. Mereka berhadapan di PTUN Semarang yang berakhir dengan kemenangan masyarakat adat, dan kemudian berhadapan di PTTUN Surabaya yang berakhir dengan kemenangan korporasi. Kedua pihak mungkin akan berhadapan lagi di lembaga pengadilan tertinggi, karena masyarakat adat SS akan mengajukan kasasi ke MA.

Perubahan kepemimpinan politik di level provinsi dan nasional mendinamisasi proses konflik, dan membuka peluang resolusi konflik. Gubernur Jawa Tengah mendorong kedua pihak utama untuk menempuh jalur litigasi. Lembaga peradilan memang telah memberikan keputusan yang bersifat menang atau kalah. Meskipun demikian, jalur litigasi ini tampak tidak efektif dalam menyelesaikan konflik karena adanya sistem peradilan yang memungkinkan masing-masing pihak untuk terus melakukan upaya banding dan kasasi.

Upaya masyarakat adat SS yang menuntut keterlibatan Lembaga Kepresidenan telah membuka peluang untuk penyelesaian konflik melalui jalur non-litigasi. Presiden telah memutuskan untuk melakukan KLHS terhadap ekosistem Pegunungan Kendeng Utara sebelum dilakukan eksploitasi batu kapur untuk pabrik semen. Dalam jangka pendek, keputusan Presiden tersebut bisa meredakan konflik. Selanjutnya, hasil KLHS akan menjadi rujukan bagi upaya mediasi oleh pihak ketiga (terutama Presiden atau Pemerintah Pusat) untuk menyelesaikan konflik ini.

Sementara kedua pihak yang berkonflik menunggu pelaksanaan KLHS, tampaknya ada kebutuhan untuk pengaturan pemanfaatan sumberdaya batu kapur di masa depan. Regulasi dan lembaga khusus yang mengatur pemanfaatan batu kapur secara lestari dan tidak melanggar HAM pernah menjadi rekomendasi 
Komnas HAM sebagai solusi terhadap konflik sosial yang timbul mengiringi rencana penambangan batu kapur untuk pabrik semen (Kompas, 6 Agustus 2016). Mengingat bahwa ketersediaan sumberdaya batu kapur yang melimpah di berbagai kawasan pegunungan di Indonesia, dan terus meningkatnya kebutuhan semen untuk pembangunan infrastruktur, ketersediaan rujukan regulatif dalam bentuk Peraturan Pemerintah tentang Ekosistem Karst, mendesak untuk disusun sebagai basis pijakan untuk pengelolaan dan perlindungan sumberdaya alam ini di masa datang.

\section{Daftar Pustaka}

AMAN (tanpa tahun). Profil Organisasi. (Online). (http://www.aman.or.id/wp-content/ uploads/2015/11/Profile-AMAN_2015.pdf, diakses 7 Januari 2017)

Apriando, Tommy.(2014).Mencari Solusi Kedaulatan Pangan di Rembug Kendeng. (Online). (http:// www.mongabay.co.id/2014/10/06/mencarisolusi-kedaulatan-pangan-di-rembugkendeng/, diakses 2 September 2016)

Apriando, Tommy. (2014). Menolak Reklamasi Menyelamatkan Teluk Benoa. (Online). (http://www.mongabay.co.id/2014/06/29/ menolak-reklamasi-menyelamatkan-telukbenoa/, diakses 2 September 2016).

Arif, Ahmad. (2014). Perlawanan Elegan dari Petani Kendeng. (Online). (http:// nationalgeographic.co.id/berita/2014/10/ perlawanan-elegan-dari-petani-kendeng, diakses 2 September 2016)

Arif, Ahmad. (2015). Perempuan Kendeng ke Istana Taguh Janji Presiden Jokowi. (Online). (http://regional.kompas.com/ read/2015/04/06/12142901/Perempuan. Kendeng.ke.Istana.Tagih.Janji.Presiden.Jok owi?search=janji+jokowi+kendeng, diakses 5 September 2016)

Askandar, Kamarulzaman (2000). Conflict and Conflict Management in Southeast Asia: Trends and Pattern. Kajian Malaysia, Jld XVIII, No. 1 \& 2. (Online). (http:// web.usm.my $/ \mathrm{km} / \mathrm{KM} \% 20 X V I I I, 1 \& 2-$ 2000 / C O N F L I C T \% 20 A N D \% 20 CONFLICT\%20MANAGMENT\%20IN\%20 SOUTHEAST\%20ASIA.pdf, diakses 7 Januari 2017).

Astuti, Eka Zuni Lusi. (2012). Konflik Pasir Besi: Pro dan Kontra Rencana Penambangan Pasir Besi di Kabupaten Kulon Progo. Jurnal Ilmu Sosial dan Ilmu Politik. Vol.16 No.1 Edisi Juli.

Bright, L. Shay. (tanpa tahun). The Conflict Mapping Chart.(Online). (http://www.in-mediation.eu/ wp-content/uploads/file/ConflictMapping. pdf, diakses 7 Januari, 2017).

Carneiro, Davide, Gomes, Marco., Novais, Paulo., Neves, José. (2014). Conflict Resolution and its Context. From the Analysis of Behavioral Patterns to Effiecient Decision-Making. (Online). (https://pdfs.semanticscholar.org/ c72b/77699ff8f5e1fdd2ed7c8c6663a1d6e4cc 12.pdf, diakses 7 Januari 2017).

Efendi, M. Noor. 18 Agustus 2013. Metamorphosis Lumbung Pangan. Suara Merdeka, hlm. 6.

Fisher, Simon., Abdi, Dekha I., Ludin, Jawed., Smith, Richard., Willias, Steve., Williams, Sue., (2000). Manajemen Konflik Keterampilan dan Strategi Untuk Bertindak. Jakarta: British Council.

Fitri, Ning. (2014). Rencana pembangunan pabrik semen, penambangan batu kapur dan tanah liat oleh PT. Indocement di Kabupaten Pati Propinsi Jawa Tengah. (Online). (http:// www.walhi.or.id/rencana-pembangunanpabrik-semen-penambangan-batu-kapurdan-tanah-liat-oleh-pt-indocement-dikabupaten-pati-propinsi-jawa-tengah.html, diakses 27 September 2016).

https://www.youtube.com/watch?v=ITIrlkdxPA, diakses 20 September 2016

h t t p s:// w w w . y o u t u b e.co m / watch? $v=Q k N$ fihKPZZE, diakses 20 September 2016

Huda, Larissa. (2016). Dijanjikan Jokowi, Ibu-Ibu Kendeng Buka Cor Kaki. (Online). (https://nasional.tempo. 
co/read/news/2016/04/14/063762547/ dijanjikan-bertemu-dengan-jokowi-ibuibu-kendeng-buka-cor-kaki, diakses 7 September 2016)

Ihsanuddin. (2016). Jokowi Penuhi Tuntutan Petani Kendeng. (Online). (http://nasional. kompas.com/read/2016/08/02/17360761/ jokowi.penuhi.tuntutan.petani.kendeng, diakses 7 September 2016)

Kholistiono. (2016). PT Indocement Kaji Perintah Presiden Jokowi Soal KLHS Pegunungan Kendeng. (Online). (http://www.murianews. com/2016/08/04/90258/pt-indocementkaji-perintah-presiden-jokowi-soal-klhspegunungan-kendeng.html, diakses 9 September 2016)

Morasso, Sara Greco (2008). The Ontology of Conflict. Pragmatics \& Cognition 16 (3): 540567. (Online). (https://www.researchgate. net/publication/233495124_The_ontology_ of_conflict, diakses 7 Januari 2017).

Novianto, Arif. (2014). Krisis Kapitalisme dan Upaya Perebutan Ruang Hidup Rakyat di Pegunungan Kendeng Utara Pati Jawa Tengah. (Online). (http://indoprogress.com/2014/05/ krisis-kapitalisme-dan-upaya-perebutanruang-hidup-rakyat-di-pegunungankendeng-utara-pati-jawa-tengah/, diakses 27 September 2016).

Nugraha, Indra (2016). Amdal Kereta Api Cepat Bandung-Jakarta Dinilai Banyak Kelemahan. (Online). (http://www.mongabay.co.id/tag/ amdal/, diakses 9 September 2016)

Nugroho, Wisnu Adhi. (2016). Indocement Ajukan 29 Keberatan ke PTTUN Surabaya. (Online). (http://www.antarajateng.com/ detail/indocement-ajukan-29-keberatan-kepttun-surabaya.html, diakses 7 September 2016

Nurdin, Nazar. (2015). Ganjar: Demo Boleh, tetapi Jangan Sampai Tutup Tutup Jalan. (Online). (http://regional.kompas.com/ $\mathrm{read} / 2015 / 08 / 04 / 19372951 / G a n j a r . D e m o$. Boleh.tetapi.Jangan.Sampai.Tutup.Jalan, diakses 5 September 2016)
(2015). Ganjar: Demo Boleh, tetapi Jangan Sampai Tutup Jalan. (Online). (http://regional. kompas.com/read/2015/08/04/19372951/ Ganjar.Demo.Boleh.tetapi.Jangan.Sampai. Tutup.Jalan, diakses 5 September 2016) . (2015). Janji Ganjar, Bupati, dan Warga Penolak Pabrik Semen. (Online). (http://regional. kompas.com/read/2015/08/13/12254291/Janji. Ganjar.Bupati.dan.Warga.Penolak.Pabrik. Semen, diakses 5 September 2016)

. (2015). Warga Gugat SK Bupati

tentang Izin Tambang Pabrik Semen. (Online). (http://regional.kompas.com/ read/2015/04/21/18091871/Warga.Gugat. SK.Bupati.tentang.Izin.Tambang.Pabrik. Semen, diakses 5 September 2016)

. (2016). PT Indocement Dukung Sikap Gubernur Ganjar soal Pabrik Semen. (Online). (http://regional.kompas.com/ read/2016/04/26/16112691/PT.Indocement. Dukung.Sikap.Gubernur.Ganjar.soal.Pabrik. Semen, diakses 7 September 2016)

Omah Kendeng. (http://omahkendeng.org/201401/1944/perlawanan-pemuda-melawanrencana-industri-semen/, diakses 2September 2016)

. (2016). Siaran Pers: LBH Semarang Kirim Kontra Memori Banding Sengketa Izin Lingkungan PT SMS. (Online). (http:// omahkendeng.org/2016-03/2320/siaranpers-lbh-semarang-kirim-kontra-memoribanding-sengketa-izin-lingkungan-pt-sms/, diakses 7 September 2016)

Pambudi, Agus. (2014). Aksi Demo, Tak Halangi Sidang Komisi AMDAL Pabrik Semen. (Online). (http://pasfmpati.com/radio/index.php/1318aksi-demo,-tak-halangi-sidang-komisiamdal-pabrik-semen, diakses 2 September 2016)

Pemerintah Indonesia. (2009). UU No. 32/2009 tentang Pengelolaan dan Perlindungan Lingkungan Hidup.

Pemerintah Indonesia. (2012). Peraturan Pemerintah (PP) No. 27/2012 tentang Izin Lingkungan. 
Pemerintah Kabupaten Pati. (2016). PTTUN Surabaya Kabulkan Permohonan Bupati Pati, Terkait Ijin Pabrik Semen. (Online). (https:// patikab.go.id/v2/id/2016/08/03/pttunsurabaya-kabulkan-permohonan-bupatipati-ter/, diakses 9 September 2016)

Pujangga, Raka F. (2014). DPRD Jateng Ajak Warga Kendeng Jalan-jalan ke Pabrik Semen. (Online). (http://jateng.tribunnews. com/2014/08/21/dprd-jateng-ajak-wargakendeng-jalan-jalan-ke-pabrik-semen, diakses 2 September 2016)

Putra, Lutfy Mairizal. (2016). Ketika "Sembilan Kartini" Bersedih dan Nekat Mengecor Kaki di Depan Istana. (Online). (http://internasional. kompas.com/read/2016/04/14/06060021/ Ketika.Sembilan.Kartini.Bersedih.dan.Nekat. Mengecor.Kaki.di.Depan.Istana.?page=all, diakses 7 September 2016)

Richard, Eko. (2016). PTTUN Surabaya Menangkan Pemkab Pati. (Online). (http:// www.wartapantura.com/2016/08/12/176/, diakses 9 September 2016)

Riski, Petrus. (2016). Keadilan Lingkungan yang Makin Mengecewakan Masyarakat. (Online). (http://www.mongabay. co.id/2016/01/06/keadilan-lingkunganyang-makin-mengecewakan-masyarakat/, diakses 7 September 2016).

Rofiuddin. (2015). 200 Penolak Pabrik Semen Gelar Aksi Jalan Kaki 100 Kilometer. (Online). (https://m.tempo.co/read/ news/2015/11/08/058716949/200-penolakpabrik-semen-gelar-aksi-jalan-kaki-100kilometer, diakses 5 September 2016)

Sandole, Dennis J.D. (1998). A Comprehensive Mapping of Conflict and Conflict Resolution: A Three Pillar Approach. Peace \& Conflict Studies. (Online), Volume 5, No. 2, 1998. (http://nsuworks.nova.edu/pcs/vol5/iss2/4/, diakses 7 Januari 2017).

Sodikin, Amir. (2015). Warga Kendeng Menangkan Gugatan, Jalan Kaki 122 Kilometer Tak Sia-sia. (Online). (http://print.kompas.com/baca/ regional/nusantara/2015/11/17/Warga-
Kendeng-Menangkan-Gugatan\%2c-JalanKaki-122-Ki, diakses 5 September 2016) Solopos. (2015). Pabrik Semen Pati: Didemo Warga, Investor Pabrik Semen Jalan Terus. (Online). (http://www.solopos.com/2015/07/24/ pabrik-semen-pati-didemo-warga-investorpabrik-semen-jalan-terus-626805, diakses 5 September 2016)

Suara Merdeka. 8 Januari 2015. Warga Tolak Pabrik Semen. (Online). (http://berita. suaramerdeka.com/smcetak/warga-tolakpabrik-semen/, diakses 5 September 2016) Suharko. (2013). Karst: Ditambang atau Dilestarikan, Konflik Sosial Rencana Pembangunan Pabrik Semen di Kabupaten Pati, Jawa Tengah. Jurnal Ilmu Sosial dan Ilmu Politik. Vol. 17 No. 2 Edisi November.

Susanto, Ari. (2015). Warga vs Pabrik Semen: Kemenangan Para Petani. (Online). (http:// www.rappler.com/indonesia/113279menolak-pabrik-semen-kendeng-patirembang, diakses 5 September 2016)

Tribunnews.com. (2016). Warga Pegunungan Kendengan Gelar Aksi Teatrikal di PTTUN Surabaya. (Online). (http://www. tribunnews.com/regional/2016/06/02/ warga-pegunungan-kendeng-gelar-aksiteatrikal-di-pt-tun-surabaya? page $=2$, diakses 7 September 2016)

Utami, Puji. (2013). Warga Pegunungan Kendengan Hadiahi Ganjar Hasil Bumi. (Online). (http://regional.kompas. com/read/2013/08/23/1646547/Warga. Pegunungan.Kendeng.Hadiahi.Ganjar. Hasil.Bumi, diakses 2 September 2016) . (2014). Aktivis Gelar Aksi Tutup Mulut Desak Batalkan Izin Pabrik Semen di Rembang. (Online). (http://regional.kompas. com/read/2014/11/05/17353721/Aktivis. Gelar. Aksi.Tutup.Mulut.Desak.Batalkan. Izin.Pabrik.Semen.di.Rembang, diakses 5 September 2016)

Walhi Jatim. (2016). Warga Kendeng Pati Mengetuk Keadilan Hakim PTTUN Surabaya. (Online). (http://walhijatim.or.id/2016/warga- 
kendeng-pati-mengetuk-keadilan-hakimpttun-surabaya/, diakses 7 September 2016)

Watchdog. (2015). SAMIN vs SEMEN (film dokumenter). (https://www.youtube. com/watch?v=1fJuJ28WZ_Q, diakses 20 September 2016).

Wehr, Paul. (1979). Conflict Regulation. Boulder, Colorado: Westview Press.

Wisanggeni, Azis. (2014). Perlawanan Pemuda Melawan Rencana Industri Semen. (Online). (http://omahkendeng.org/2014-01/1944/ perlawanan-pemuda-melawan-rencanaindustri-semen/, diakses 2 September 2016)

\section{Sumber Data Sekunder}

Kompas, 22 Mei 2011

Kompas, 2 Maret 2013

Kompas, 13 April 2016

Kompas, 14 April 2016

Kompas, 3 Agustus 2016

Kompas, 4, Agustus 2016

Kompas, 6 Agustus 2016 